\title{
Specyfika i zakres prawa finansowego Unii Europejskiej
}

\section{The specificity and scope of \\ European Union finance law}

Streszczenie. Zasadniczo polska nauka prawa finansowego dosyć szeroko podejmuje problematykę związaną z finansami publicznymi Unii Europejskiej (UE). Zauważyć jednak należy, że rozważania w dużej mierze odnoszą się do zagadnień szczegółowych prawa finansowego UE, np. w obszarach harmonizacji podatkowej czy jednolitego rynku finansowego. Występuje natomiast niedosyt lub nawet znikomość publikacji o charakterze doktrynalno-teoretycznym, odnoszących się do ogólnych i zasadniczych zagadnień prawa finansowego UE. Do takich zaliczyć można m.in. kwestie definicyjne, zakres i strukturę wewnętrzną tego prawa, jego źródła etc. Generalnie należy wskazać na dwa obszary, które powinny stać się przedmiotem badań podstawowych w odniesieniu do wskazanych powyżej elementów. Pierwszy to prawo finansowe samej UE, a drugi - to jego wpływ i skutki tego wpływu na polskie prawo finansowe. W niniejszym artykule podjęte zostaną rozważania odnoszące się do tego pierwszego obszaru, mające na celu określenie specyfiki oraz zakresu prawa finansowego UE. 
Słowa kluczowe: prawo finansowe UE; koordynacja polityki gospodarczej UE; kompetencje wyłączne i niewyłączne; zasada przyznania; zasady pomocniczości i proporcjonalności.

\begin{abstract}
Basically, Polish science of financial law quite broadly takes the problems concerning public finance of the European Union (EU). However, it should be noticed that the considerations largely refer to the detailed issues within the confines of individual branches of EU financial law, eg. in areas of tax harmonization or single financial market. At the same time there is an insufficiency or even minuteness publications with doctrinal and theoretical nature referring to the general and fundamental issues of financial law of the EU. There may be numbered such issues among others as definitions, scope and internal structure of this law, its legal sources etc. Generally two areas should be object of the basic scientific researches in reference to the issues mentioned above. First one is financial law of the EU and the second one - its influence and effect of this influence on Polish financial law. In this article there will be undertaken considerations referring to the first area aimed at defining the specifity and scope of EU financial law.

Keywords: financial law of the EU; EU economic policy coordination, principle of conferral; exclusive and shared competences; principles of subsidiarity and proportionality.
\end{abstract}

\title{
1. Uwagi wprowadzające
}

Zasadniczo polska nauka prawa finansowego dosyć szeroko podejmuje zagadnienia związane z finansami publicznymi Unii Europejskiej (UE). Zainteresowanie tą problematyką wzrosło - co wydaje się być naturalne po akcesji Polski, tym bardziej że rozwiązania (instytucje) finansowe przyjęte w prawie unijnym stały się częścią polskiego systemu prawnego. Zauważyć jednak należy, że rozważania doktryny w dużej mierze odnoszą się do zagadnień szczegółowych prawa finansowego UE ${ }^{1}$. Dla przykładu

1 W literaturze zachodniej (a także amerykańskiej) rzadko występuje pojęcie „prawa finansowego". Jeżeli jest już podejmowana problematyka przedmiotu jego regulacji a więc finansów publicznych - to częściej pojawia się ona w publikacjach o charakterze ekonomicznym niż prawniczym. Co więcej, powszechnie stosowany jest termin 
można wskazać, że bardzo często podejmuje się problemy związane z harmonizacją podatkową oraz wpływem podatkowych regulacji zawartych w prawie Unii na polski system podatkowy. Nie mniejsze zainteresowanie budzi również prawo jednolitego rynku finansowego UE.

Na kanwie tych spostrzeżeń zauważyć należy jednak występujący niedosyt lub nawet znikomość publikacji poświęconych rozważaniom o charakterze doktrynalno-teoretycznym na temat ogólnych i zasadniczych kwestii dotyczących prawa finansowego UE, wśród których można wymienić kwestie definicyjne, zakres i strukturę tego prawa, jego źródła etc.

Powodem, dla którego wskazywane zagadnienia powinny stanowić przedmiot szerokiego zainteresowania, było przystąpienie Polski do struktur unijnych. Jednym ze skutków tego procesu było przyjęcie całego dorobku Wspólnot i Unii Europejskiej określanego jako acquis communautaire, co również nie pozostało bez wpływu na polskie prawo finansowe. Tradycyjne jego rozumienie musi ulec zmianie $\mathrm{w}$ wielu elementach, w szczególności w odniesieniu do samej definicji, źródeł, struktury wewnętrznej.

Można więc wskazać na dwa obszary, które powinny stać się przedmiotem badań podstawowych w odniesieniu do wskazanych powyżej elementów. Pierwszy to prawo finansowe samej UE, a drugi - to jego wpływ i skutki tego wpływu na polskie prawo finansowe. Obszary te są bardzo rozległe, bowiem - co wskazywał autor - obejmują wiele kluczowych zagadnień. Natomiast w niniejszym artykule podjęte zostaną rozważania odnoszące się do tego pierwszego obszaru, mające na celu określenie specyfiki oraz zakresu prawa finansowego UE.

\section{Elementy determinujące kształt prawa finansowego Unii Europejskiej}

W zasadzie odpowiedź na pytanie o zakres (kształt) prawa finansowego UE w pierwszej kolejności powinna się sprowadzać do wyjaśnienia istoty unijnej polityki finansowej, a w szerszym znaczeniu - polityki gospodar-

„finanse publiczne” niż „prawo finansowe”, nawet gdy podejmowane są prawne zagadnienia finansów publicznych. 
czej. Charakter tej polityki determinuje bowiem stosowane instrumenty służące jej realizacji, a jednym z nich są normy prawne ${ }^{2}$.

Szeroko pojęta polityka gospodarcza UE wykazuje znaczną specyfikę w stosunku do klasycznego rozumienia polityki gospodarczej państwa i ma złożony charakter. Wynika to $\mathrm{z}$ faktu, że z jednej strony Unia jako samodzielna organizacja międzynarodowa, posiadająca osobowość prawną i własne instytucje, w oparciu o środki publiczne, zgromadzone w m.in. rocznym budżecie ogólnym, dokonuje określonych posunięć (decyzji) finansowych. Z drugiej strony wszystkie państwa członkowskie, konstruując budżety krajowe oraz tworząc normy prawno-finansowe, również realizują własne polityki fiskalne, a w szerszym zakresie - polityki gospodarcze. Państwa te jednak funkcjonują w określonym otoczeniu ekonomicznym i prawnym, które w dużej mierze jest determinowane członkowstwem w UE. Na otoczenie to wpływają ogólne cele Unii określone w art. 3 Traktatu o Unii Europejskiej ${ }^{3}$. W sferze gospodarczej skupiają się one w szczególności na: 1) stworzeniu jednolitego rynku wewnętrznego, realizowanego poprzez zasady swobody przepływu towarów, osób, usług i kapitału; 2) uzyskaniu trwałego rozwoju Europy opartego o zrównoważony wzrost gospodarczy, stabilność cen, społeczną gospodarkę rynkową o wysokiej konkurencyjności; 3) integracji walutowej w ramach unii gospodarczej i walutowej. Tym samym państwa członkowskie stają się również aktorami polityki gospodarczej całej Unii, a to z kolei wymusza potrzebę koordynacji ich działań.

O tym, w jakim w jakich dziedzinach i w jakim zakresie UE ma kompetencje do działania (ponieważ nie są one nieograniczone) stanowi zasada przyznania określona w art. 5 TUE. Na jej podstawie Unia jest uprawniona do działania wyłącznie w granicach kompetencji przyznanych jej przez państwa członkowskie $\mathrm{w}$ traktatach, niezbędnych do osiągnięcia celów w tych traktatach określonych, m.in. w art. 3 TUE. Natomiast kompetencje nieprzyznane mogą wykonywane tylko przez państwa członkowskie.

2 E. Ruśkowski, Polityka finansowa, [w:] E. Ruśkowski (red.), Finanse publiczne i prawo finansowe, t. 1, Warszawa 2000, s. 28.

3 Traktat o Unii Europejskiej (Dz.Urz. UE z dnia 26.10.2012 r., C 326, s. 1 - wersja skonsolidowana, dalej: TUE). 
Nawet jednak w przypadku kompetencji przyznanych Unia nie ma pełnej swobody podejmowania inicjatywy z pominięciem państw członkowskich. Jest tak z dwóch powodów. Po pierwsze, z postanowień traktatów, a wprost z art. 2 Traktatu o funkcjonowaniu Unii Europejskiej ${ }^{4}$, wynika podział kompetencji przyznanych Unii na kompetencje wyłączne i niewyłączne. Te ostatnie wykonywane są wspólnie z państwami członkowskimi. Ale również w przypadku kompetencji wyłącznych państwa mogą wykazywać inicjatywę. Z jednej strony poprzez wydawanie wiążących aktów prawnych, o ile Unia upoważni je do tego, z drugiej - mogą przyjmować akty prawne w celu wykonywania aktów ustanowionych przez samą Unię.

Po drugie, swoboda realizacji działań Unii na podstawie zasady przyznania została ograniczona wynikającymi z niej zasadami proporcjonalności i pomocniczości. Pierwsza z nich, określona w art. 5 ust. 4 TUE, ma zastosowanie do wszystkich kompetencji przyznanych Unii (wyłącznych i niewyłącznych). Stanowi ona, iż zakres i forma działania Unii nie wykraczają poza to, co jest konieczne dla osiągnięcia celów traktowych.

Druga z zasad - zasada pomocniczości, której podstawą prawną jest art. 5 ust. 3 TUE - ma zastosowanie w dziedzinach, w których Unii przyznano kompetencje niewyłączne wspólnie z państwami członkowskimi. Na podstawie tej zasady Unia podejmuje działania wówczas i tylko w takim zakresie, w jakim cele zamierzonego działania nie mogą być osiągnięte w wystarczający sposób przez państwa członkowskie i jeśli ze względu na rozmiary lub skutki proponowanego działania możliwe jest lepsze ich osiągnięcie na poziomie Unii.

Reasumując, zgodnie z zasadą przyznania dokonuje się wyodrębnienia kompetencji przyznanych Unii, pozostałe zaś stanowią kompetencje nieprzyznane, które mogą być wykonywane wyłącznie przez państwa członkowskie. Z kolei w obrębie kompetencji przyznanych, przepisy traktatów precyzują, które z dziedzin działalności (także o charakterze gospodarczym) są realizowane przez UE samodzielnie (kompetencje wyłączne - art. 2 ust. 1 i art. 3 TFUE), a które wspólnie z państwami członkowskimi

4 Traktat o funkcjonowaniu Unii Europejskiej (Dz.Urz. UE z dnia 26.10.2012 r., C 326, s. 47 - wersja skonsolidowana, dalej: TFUE). 
(kompetencje niewyłączne). W zależności od poglądów doktryny kompetencje niewyłączne są różnie klasyfikowane. Przykładowo w ramach tej kategorii wyróżnia się kompetencje dzielone (art. 2 ust. 2 i art. 4 TFUE), kompetencje koordynacyjne w odniesieniu do polityk gospodarczych i zatrudnienia (art. 2 ust. 3 i art. 5 TFUE), kompetencje uzupełniające (art. 2 ust. 5 i art., 6 TFUE) i dodatkowo odrębny rodzaj kompetencji w zakresie wspólnej polityki zagranicznej i bezpieczeństwa (art. 2 ust. 4 TFUE) ${ }^{5}$. Z kolei zgodnie z innym stanowiskiem można mówić o dwóch rodzajach kompetencji - dzielonych i uzupełniających. W tym przypadku grupą kompetencji dzielonych objęto wskazane obszary koordynacji oraz wspólną politykę zagraniczną i bezpieczeństwa, ponieważ pozostają one poza zakresem regulacji art. 3 i 6 TFUE ${ }^{6}$. Co więcej, potrzebę koordynacji polityk gospodarczych i zatrudnienia można wyinterpretować $\mathrm{z}$ art. 4 TFUE, określającego dziedziny, w których występują kompetencje dzielone. Część z tych dziedzin dotyczą właśnie polityk gospodarczych i zatrudniania, a fakt podziału kompetencji wymaga koordynacji.

Poza kategoryzacją kompetencji TFUE precyzuje w których dziedzinach mają one zastosowanie. I tak, zgodnie $\mathrm{z}$ art. 3 Unia posiada kompetencje wyłączne m.in. w takich dziedzinach jak: unia celna, konkurencja na rynku wewnętrznym, polityka pieniężna, wspólna polityka handlowa. Następnie, w świetle art. 4 kompetencje dzielone występują m.in. w następujących dziedzinach: rynek wewnętrzny, polityka społeczna (ale tylko w odniesieniu do aspektów uwzględnionych w Traktacie), spójność gospodarcza, społeczna i terytorialna, środowisko, ochrona konsumentów, transport. Z kolei kompetencje uzupełniające odnoszą się w szczególności do: ochrony i poprawy zdrowia ludzkiego, przemysłu, kultury, turystyki, edukacji, kształcenia zawodowego.

R. Schütze, European Consitutional Law, Cambridge 2012, s. 162 i n.

K. Lenaerts, P. Van Nuffel, European Union Law, London 2011, s. 128. 


\section{Zakres i formy koordynacji polityki fiskalnej UE}

Fakt kategoryzacji kompetencji, a w szczególności wyróżnienie kompetencji dzielonych pomiędzy UE a państwa członkowskie dla osiągnięcia celów traktatowych, wymusza podejmowanie działań koordynacyjnych, aby realizowana polityka gospodarcza (finansowa) Unii jako organizacji skupiającej 28 członków charakteryzowała się spójnością. Co więcej, powinny zostać wyznaczone ośrodki decyzyjne, które będą odpowiedzialne za przeprowadzanie takich działań koordynacyjnych.

Zakres i formy koordynacji polityki gospodarczej UE wynikają przede wszystkim z postanowień traktatowych. Aczkolwiek należy mieć na względzie aspekt historyczny procesów integracji gospodarczej, w tym walutowej, dokonujących się w ramach Europejskiej Wspólnoty Gospodarczej, a następnie Wspólnoty Europejskiej i samej Unii, który miał wpływ na obecny kształt polityki gospodarczej i formy jej koordynacji ${ }^{7}$. W istocie procesy historyczne zdeterminowały obecnie obowiązujące rozwiązania prawne, nie tylko o charakterze traktatowym.

Formy koordynacji polityki gospodarczej UE pośrednio są determinowane powoływaną zasadą przyznania oraz wyodrębnieniem kompetencji wyłącznych i dzielonych w poszczególnych dziedzinach. Konsekwencją tego podziału są regulacje traktatowe, które wprost wskazują na obowiązek koordynacji, tj.:

- $\quad$ art. 5 i art. 120-121 TFUE - określające ogólny obowiązek koordynacji polityk gospodarczych państw członkowskich w ramach Rady, mając na względzie cele określone w art. 3 Traktatu;

- $\quad$ art. 119 ust. 1 TFUE - nakazujący zachowanie ścisłej koordynacji polityk gospodarczych państw członkowskich, mając na względzie cele określone w art. 3 Traktatu;

- art. 119 ust. 2 TFUE - określający obowiązek koordynacji w odniesieniu do polityki pieniężnej i polityki wymiany walut, która ma być realizowana w sposób jednolity, tzn. jako jednolita polityka pieniężna i jednolita polityka wymiany walut.

\footnotetext{
7 Zob. szerzej w K. Lenaerts, P. Van Nuffel, European Union..., s. 379-381.
} 
Powoływane przepisy wskazują na obszary działań koordynacyjnych UE i państw członkowskich. Jednakże na bazie ogólnego obowiązku koordynacji polityk gospodarczych, szczególny nacisk położono na integrację walutową w ramach jednej waluty euro. Działania koordynacyjne w tym obszarze są bardziej intensywne niż w pozostałych dziedzinach, w wyniku czego polityka pieniężna oraz polityka wymiany walut mają wymiar jednolity dla wszystkich państw członkowskich ${ }^{8}$, a ich głównym celem jest utrzymanie stabilności cen. Dodatkowym celem tych polityk jest wspieranie ogólnych polityk gospodarczych w Unii, ale z zastrzeżeniem, że nie może się to odbywać z uszczerbkiem dla stabilności cen, która posiada charakter priorytetowy. Z takim brzmieniem art. 119 ust. 2 TFUE koresponduje art. 127 ust. 1 określający nadrzędny cel Europejskiego Systemu Banków Centralnych, jakim jest utrzymanie stabilności cen, oraz cel uzupełniający - wspieranie polityk gospodarczych w UE, ale bez uszczerbku dla celu nadrzędnego.

Bez względu na wyodrębnienie z ogólnych polityk gospodarczych UE, polityki pieniężnej i wymiany walut podlegających silniejszej koordynacji, wszystkie polityki powinny być realizowane przy zachowaniu następujących zasad: otwartej gospodarki rynkowej opartej na wolnej konkurencji, stabilności cen, zdrowych finansów publicznych i warunków pieniężnych oraz trwałej równowagi płatniczej.

Mając na uwadze przytoczone powyżej regulacje, stwierdzić trzeba, że koordynacja polityki gospodarczej w UE odbywa się we wskazanych poniżej formach $^{9}$. Zauważyć przy tym należy, że są to pewne modele i nie zawsze konkretna polityka, która jest realizowana w danej formie, będzie odpowiadać wszystkim jej cechom.

1. Jednolita polityka (single policy), w której Unia posiada kompetencje wyłączne, co oznacza, że działa samodzielnie i niezależnie. Ośrodek

8 Jednolitej polityce pieniężnej i wymiany walut nie podlegają państwa członkowskie objęte tzw. derogacją, a więc znajdujące się w II etapie unii gospodarczej i walutowej (zob. art. 139-144 TFUE). Ponadto wyłączone z nich zostało Zjednoczone Królestwo Wielkiej Brytanii i Irlandii Północnej.

9 European Commission, Directorate-General for Economic and Financial Affairs, Coordination of economic policies in the EU: a presentation of key features of the main procedures, „Euro Papers” 2002, nr 45, s. 4. 
decyzyjny polityki realizowanej w tej formie został umiejscowiony na poziomie ponadnarodowym. Za ustalanie jej kierunków i sposobu wykonywania odpowiada wyznaczony organ (instytucja) UE. Rola państw członkowskich sprowadza się głównie do przyjmowania tych kierunków i uczestnictwa w realizacji polityki na ustalonych zasadach. W formie jednolitej polityki realizowane są polityki pieniężna, walutowa, celna, konkurencji oraz budżetowa, której głównym instrumentem jest budżet ogólny UE. Przepisy traktatowe wprost wskazują, że forma ta jest właściwa dla polityki pieniężnej i walutowej, ale na podstawie pozostałych przepisów traktatowych i prawa wtórnego można uznać, że w sposób jednolity są również koordynowane pozostałe wskazane polityki.

2. Ścisła koordynacja (close coordination), która opiera się na podziale kompetencji pomiędzy Unią a państwami członkowskimi. Jej istota polega na tym, że ogólne cele, które mają być osiągnięte, wyznaczone zostają przez organy Unii, z kolei państwom członkowskim przyznaje się swobodę wyboru instrumentów służących osiągnięciu tych celów. Przykładami polityk koordynowanych $\mathrm{w}$ tej formie są polityka podatkowa (poprzez harmonizację podatkową), polityka strukturalna związana z funkcjonowaniem rynku wewnętrznego, polityka w zakresie jednolitego rynku finansowego, polityka budżetowa w odniesieniu do salda budżetowego i długu publicznego państw członkowskich oraz $\mathrm{w}$ zakresie sprawowania w stosunku do nich nadzoru budżetowego.

3. Luźna koordynacja (weak coordination) posiadająca bardzo ogólny i szeroki charakter, jednakże niewiążąca prawnie państw członkowskich. W związku z tym realizowana jest za pomocą „miękkich” instrumentów, takich jak wytyczne, opinie czy zalecenia, a państwa członkowskie wykonują ją na zasadzie dobrowolności, np. polityka budżetowa w odniesieniu do jakości finansów publicznych. 


\section{Struktura prawa finansowego Unii Europejskiej}

Określenie struktury prawa finansowego UE jest o tyle skomplikowane, że przepisy (normy) składające się na to prawo mają niejednorodny charakter. Nie bez powodu autor na początku artykułu podjął rozważania na temat zasady przyznania oraz podziału kompetencji. Wszystkie te elementy wpływają na zróżnicowany charakter polityki gospodarczej UE. Instrumentami służącymi jej realizacji są przepisy, z których część tworzy prawo finansowe tej organizacji. Tak więc specyfika prawa finansowego polega na złożonym charakterze unijnych regulacji ${ }^{10}$. Ich klasyfikacja może obywać się według różnych kryteriów, a w szczególności: kryterium przedmiotu (zakresu) regulacji, kryterium adresatów, kryterium obowiązywania i stosowania. Równocześnie kryteriami tymi można posłużyć dla określenia struktury prawa finansowego UE, co jest celem niniejszego artykułu.

Wydaje się, że kluczowym kryterium jest przedmiot (zakres) regulacji prawa finansowego, z którym istotnie wiąże się również kryterium adresatów. Uzasadnione to jest podziałem kompetencji Unii na wyłączne i dzielone oraz koordynacją polityki gospodarczej. Ponadto nie bez znaczenia pozostaje kryterium obowiązywania i stosowania prawa finansowego UE, ale ze względu na ograniczone ramy niniejszej publikacji pozostanie ono poza przedmiotem rozważań.

Uwzględniając zatem treść przepisów regulujących finanse publiczne UE, jej prawo finansowe może być rozpatrywane w znaczeniu wąskim (sensu stricto) i szerokim (sensu largo) ${ }^{11}$.

10 Na niejednorodność prawa finansowego UE zwraca uwagę C. Kosikowski. Zob. C. Kosikowski, Finanse i prawo finansowe Unii Europejskiej, Warszawa 2014, s. $172-173$.

11 Na marginesie należy wskazać, że podział polskiego prawa finansowego ze względu na zakres norm nim objętych zastosował E. Ruśkowski. Wyróżnił on prawo finansowe w sensie wąskim (sensu stricto), prawo finansowe w sensie pośrednim (sensu largo), prawo finansowe w sensie najszerszym (sensu largissimo). Zob. E. Ruśkowski, Prawo finansowe, [w:] E. Ruśkowski, J. Stankiewicz, Finanse i prawo finansowe, Białystok 1991, s. 29-31. 
Na prawo finansowe UE w sensie wąskim przede wszystkim będą składały się przepisy dotyczące finansów Unii jako odrębnej organizacji. Ponadto związane są one z politykami realizowanym w formie jednolitej. Przepisy te dotyczą ustroju walutowego Unii, bankowości centralnej oraz jej gospodarki finansowej, opartej zarówno na budżecie ogólnym, jak i na pozostałych instytucjach pozabudżetowych. W związku z tym tworzą one swego rodzaju „Prawo finansów UE”12, bądź też „Prawo o finansach UE”. Takich pojęć można użyć dla celów klasyfikacyjnych, choć mniej ważna jest tu stosowana terminologia, a większe znaczenie powinno przywiązywać się do specyfiki regulacji. Precyzując zakres prawa finansowego UE sensu stricte, należy wskazać, że znajdą się w nim regulacje prawne dotyczące:

1. unii gospodarczej i walutowej, opartej na wspólnej walucie euro;

2. funkcjonowania Europejskiego Systemu Banków Centralnych na czele z Europejskim Bankiem Centralnym;

3. wieloletniego planowania finansowego, którego głównym instrumentem są wieloletnie ramy finansowe (perspektywy finansowe);

4. budżetu ogólnego UE, w szczególności jego dochodów, wydatków (w tym instrumentów finansowych), procedury uchwalania i wykonywania budżetu, absolutorium i kontroli budżetowej;

5. pozabudżetowych instytucji i instrumentów finansowych, np. agencji wykonawczych, zdecentralizowanych agencji unijnych, Europejskiego Banku Inwestycyjnego, Europejskiego Funduszu Inwestycyjnego, Europejskiego Funduszu Rozwoju ${ }^{13}$;

6. ochrony interesów finansowych Unii;

7. unii celnej.

Adresatami przepisów tej grupy przepisów będą zarówno organy (instytucje) unijne, jak i państwa członkowskie. Dla tych pierwszych stanowią one regulacje, których przedmiotem jest ustrój finansowy Unii.

12 Regulacje o takim charakterze C. Kosikowski określa jako wewnętrzne prawo finansowe UE. Zob. C. Kosikowski, Finanse i prawo finansowe..., s. 172-173.

13 Przeważająca część funduszy unijnych znajduje się budżecie ogólnym UE i środki $\mathrm{z}$ nich ponoszone stanowią wydatki budżetowe. Wśród funduszy ujętych w budżecie unijnym można wymienić m.in.: Europejski Fundusz Rozwoju Regionalnego, Europejski Fundusz Społeczny, Fundusz Spójności. 
Z kolei przestrzeganie norm prawnofinansowych tej grupy przez państwa członkowskie jest uzasadnione ich przynależnością do UE, czego konsekwencją jest realizacja przyznanych im praw oraz podleganie nałożonym obowiązkom, np. przekazywanie dochodów do budżetu unijnego, wydatkowanie środków z budżetu unijnego $\mathrm{w}$ ramach określonych funduszy (tzw. dzielone zarządzanie budżetem ${ }^{14}$ ).

$\mathrm{Z}$ kolei prawo finansowe UE $\mathrm{w}$ znaczeniu szerokim, obok regulacji dotyczących ustroju finansowego samej Unii, obejmie także te, które służą budowie rynku wewnętrznego oraz realizacji zasad swobody przepływu towarów, osób, usług i kapitału. Adresatów tej drugiej grupy przepisów stanowią przede wszystkim państwa członkowskie. Do ich podstawowych obowiązków będzie należeć albo realizacja norm wynikających bezpośrednio z aktów prawnych Unii, albo podejmowanie czynności implementacyjnych prawa unijnego i zapewnienie jego skuteczności w krajowych porządkach prawnych (implementacja zupełna prawa UE). Przepisy te więc będą kierowane tylko do państw członkowskich. Rola instytucji unijnych sprowadzać się będzie do sprawowania kontroli nad wykonywaniem tych obowiązków i stosowania przymusu prawnego wobec państw, które dopuściły się naruszeń w tym zakresie, np. poprzez wszczynanie postępowań wstępnych przez Komisję Europejską czy kierowanie skarg z tytułu nieprawidłowej implementacji prawa unijnego do Europejskiego Trybunału Sprawiedliwości na podstawie art. 258 TFUE.

Wśród grupy regulacji prawa finansowego UE sensu largo, tzn. wyłącznie kierowanych do państw członkowskich ${ }^{15}$, można wskazać na te, które w szczególności dotyczą:

1. spełnienia kryteriów konwergencji;

2. przestrzegania tzw. wartości referencyjnych deficytu budżetowego i długu publicznego państw członkowskich;

14 Art. 59 rozporządzenia Parlamentu Europejskiego i Rady (UE, Euratom) nr 966/2012 z dnia 25 października 2012 r. w sprawie zasad finansowych mających zastosowanie do budżetu ogólnego Unii oraz uchylające rozporządzenie Rady (WE, Euratom) nr 1605/2002 (Dz.Urz. UE z dnia 26.10.2012 r., L 298, s. 1 ze zm.).

15 Zdaniem C. Kosikowskiego przepisy o takim charakterze tworzą zewnętrzne prawo finansowe UE. Zob. C. Kosikowski, Finanse i prawo finansowe..., s. 172-173. 
3. sprawowania nadzoru budżetowego w państwach członkowskich w różnych aspektach, np. planowania budżetowego, przekazywania programów i sprawozdań, realizacji procedur nadmiernego zakłócenia równowagi makroekonomicznej w państwach członkowskich;

4. harmonizacji podatkowej oraz współpracy administracyjnej w sprawach podatkowych;

5. jednolitego rynku finansowego UE.

W dużej części powyższe przepisy objęte są ramami dyrektyw, co implikuje potrzebę ich implementacji przez państwa członkowskie. Zgodnie bowiem z art. 288 akapit 3 TFUE dyrektywa wiąże każde państwo członkowskie, do którego jest kierowana, w zakresie rezultatu, który ma być osiągnięty. Jednocześnie pozostawia im swobodę wyboru formy i środków.

\section{Wnioski końcowe}

Rozważania podjęte $\mathrm{w}$ niniejszym artykule na temat prawa finansowego UE sprowadzają się do następujących wniosków końcowych.

1. Elementami wpływającymi na strukturę (kształt) prawa finansowego UE są traktatowa zasada przyznania, podział kompetencji przyznanych Unii i państwom członkowskim dla realizacji celów traktatowych oraz wynikająca z tego podziału potrzeba koordynacji polityki gospodarczej całej UE.

2. Specyfika prawa finansowego UE głównie polega na niejednorodnym charakterze regulacji prawnych, składających się na to prawo.

3. W związku z niejednorodnością regulacji prawnych, dokonać można podziału prawa finansowego UE na prawo finansowe w znaczeniu wąskim (sensu stricto) i prawo finansowe w znaczeniu szerokim (sensu largo).

4. Prawo finansowe UE sensu stricto tworzone będzie przez regulacje prawne dotyczące finansów Unii jako odrębnej organizacji. Są one związane z politykami realizowanym w formie jednolitej. Regulacje te stanowią o ustroju walutowym Unii, bankowości centralnej oraz 
jej gospodarce finansowej. Adresatami przepisów tej grupy będą zarówno organy (instytucje) unijne, jak i państwa członkowskie. Dla tych pierwszych stanowią one regulacje, których przedmiotem jest ustrój finansowy Unii. Z kolei przestrzeganie przez państwa członkowskie jest uzasadnione przyznanymi prawami i nałożonymi obowiązkami w związku z ich przynależnością do UE.

5. Prawo finansowe UE sensu largo, obok regulacji dotyczących ustroju finansowego samej Unii, obejmie także te, które służą budowie rynku wewnętrznego oraz realizacji zasad swobody przepływu towarów, osób, usług i kapitału. Adresatów tych norm stanowią przede wszystkim państwa członkowskie. Do ich podstawowych obowiązków będzie należeć albo realizacja norm wynikających bezpośrednio z aktów prawnych Unii, albo podejmowanie czynności implementacyjnych prawa unijnego i zapewnienie jego skuteczności w krajowych porządkach prawnych (implementacja zupełna prawa UE).

\section{Bibliografia:}

European Commission, Directorate-General for Economic and Financial Affairs, Coordination of economic policies in the EU: a presentation of key features of the main procedures, „Euro Papers” 2002, nr 45.

Kosikowski C., Finanse i prawo finansowe Unii Europejskiej, Wolters Kluwer, Warszawa 2014.

Lenaerts K., Van Nuffel P., European Union Law, Sweet \& Maxwell, London 2011.

Ruśkowski E., Polityka finansowa, [w:] Ruśkowski E. (red.), Finanse publiczne i prawo finansowe, t. 1, Konieczny i Kruszewski, Warszawa 2000.

Ruśkowski E., Prawo finansowe, [w:] Ruśkowski E., Stankiewicz J., Finanse i prawo finansowe, Era s.c., Białystok 1991.

Schütze R., European Consitutional Law, Cambridge University Press, Cambridge 2012. 